\title{
Agrobacterium-mediated transient transformation of Mexican prickly poppy (Argemone mexicana L.)
}

\author{
Gregorio Godoy-Hernández* \\ Unidad de Bioquímica y Biología Molecular de Plantas \\ Centro de Investigación Científica de Yucatán \\ A.C. C. 43 No. 130, Chuburná de Hidalgo 97200 \\ Mérida, Yucatán, México \\ Tel: 9999428330 \\ Fax: 9999813900 \\ E-mail: ggodoy@cicy.mx
}

\section{Elidé Avilés-Berzunza}

Unidad de Bioquímica y Biología Molecular de Plantas Centro de Investigación Científica de Yucatán

A.C. C. 43 No. 130, Chuburná de Hidalgo 97200

Mérida, Yucatán, México

Tel: 9999428330

Fax: 9999813900

E-mail: avibeli@cicy.mx

\section{Mildred Carrillo-Pech}

Unidad de Bioquímica y Biología Molecular de Plantas

Centro de Investigación Científica de Yucatán

A.C. C. 43 No. 130, Chuburná de Hidalgo 97200

Mérida, Yucatán, México

Tel: 9999428330

Fax: 9999813900

E-mail: mild@cicy.mx

\section{Felipe Vázquez-Flota}

Unidad de Bioquímica y Biología Molecular de Plantas

Centro de Investigación Científica de Yucatán

A.C. C. 43 No. 130, Chuburná de Hidalgo 97200

Mérida, Yucatán, México

Tel: 9999428330

Fax: 9999813900

E-mail: felipe@cicy.mx

Website: http://www.cicy.mx

Financial support: Consejo Nacional de Ciencia y Tecnología (CONACYT) from México (Grant No. 28643-B).

Keywords: Argemone mexicana, $\beta$-glucuronidase, benzylisoquinoline alkaloids, genetic transformation, neomycin phosphotransferase II.

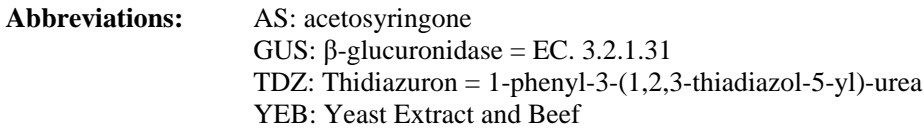

Shoot apex, leaf primordia, leaf sections and roots from Mexican prickly poppy seedlings, were inoculated with Agrobacterium tumefaciens harboring the binary vector pCAMBIA2301, which contained the $\beta$-glucuronidase (uid A) gene. Histochemical $\beta$-glucuronidase (GUS) assay in infected explants showed transient gus gene expression between 3 and 12 days after inoculation. To our knowledge, this is the first report of $A$. mexicana susceptibility to $A$. tumefaciens-mediated genetic transformation.
The genus Argemone (Papaveraceae) comprises almost 30 species, all with prickly stems, leaves and capsules. Argemone mexicana L., commonly known as Mexican or prickly poppy, is native to tropical America, but has widely spread to many tropical and sub-tropical regions. It is frequently found as a weed in cultivated and abandoned fields. It is an annual, hermaphroditic shrub, mostly pollinated by insects, with terminal bright yellow flowers (Rao and Dave, 2001). In Mexican traditional medicine,

\footnotetext{
*Corresponding author
} 

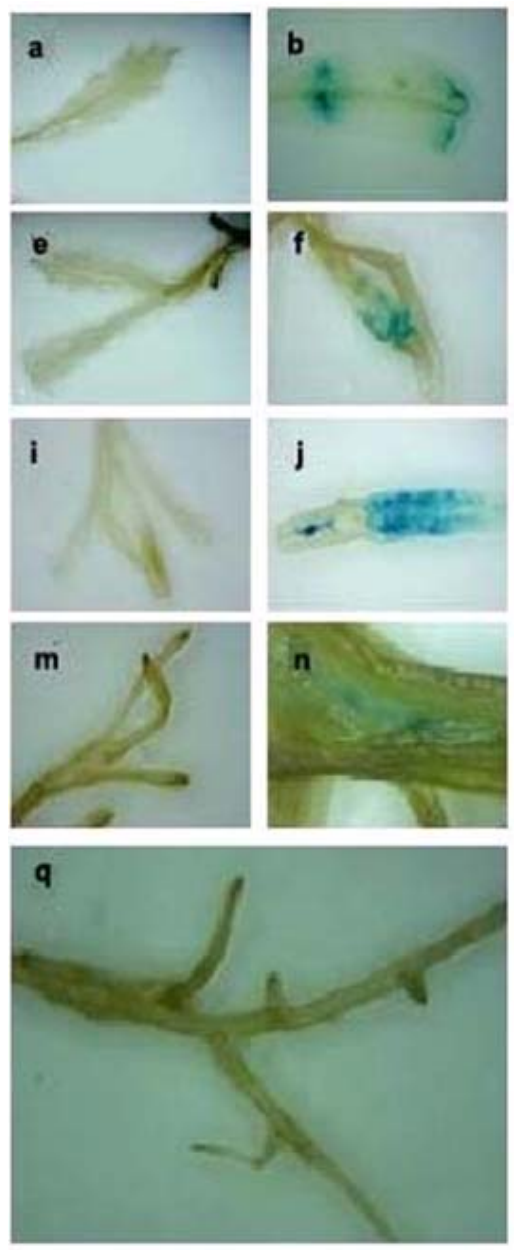
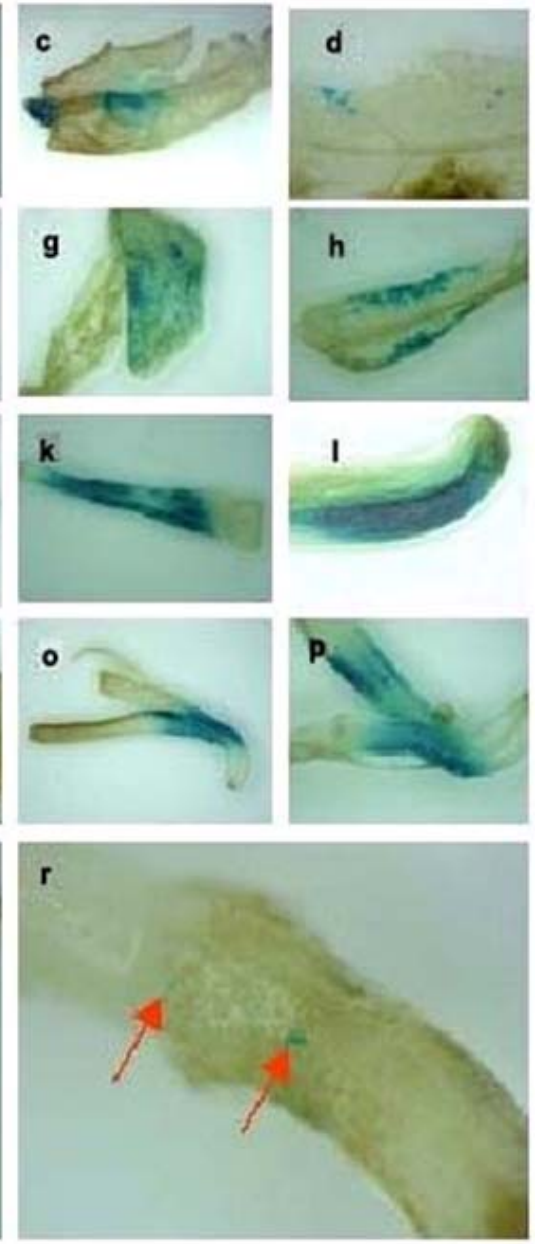

Figure 1. Histochemical GUS assays performed on transformed explants of Argemone mexicana L. Explants were transformed with the binary vector pCAMBIA2301 via Agrobacterium tumefaciens (strain LBA4404). (a), (e), (i), (m) and (q), negative, untransformed controls; (b), (c), (d), (f), (g), (h), (j), (k) and (l), transiently transformed leaves; (n), (o) and (p), transiently transformed shoot-apex sections; (r): transiently transformed roots. The arrows point to GUS expression foci.

Argemone plants have been used to treat different skin and eye ailments.

Seeds are rich in non saturated fatty acids, such as linoleic, oleic, ricinoleic, and palmitoleic acids. Nevertheless, their high content of toxic compounds may hamper their use with industrial purposes. In fact, the presence of Argemone oil in edible mustard oil is probably responsible for outbreaks of epidemic dropsy, a clinical syndrome characterized by edema, cardiac insufficiency, renal failure and glaucoma, which is attributed to sanguinarine, the main Argemone alkaloid (García et al. 2006). Sanguinarine is a quaternary benzophenanthridine alkaloid with a strong bactericidal effect on Gram-positive bacteria (Rao and Dave, 2001). It also displays anti-inflammatory and cytotoxic activities. The antimicrobial and physiological effects of sanguinarine suggest that it may confer protection against diverse pathogens (Facchini, 2001).
Other identified alkaloids in Argemone include berberine, protopine and coptisine (Facchini, 2001). The complex alkaloid mixture of this plant is perhaps the basis for its allelopathic, nematicidal and bactericidal effects. In this way, A. mexicana has many potential uses, some of them derived of the presence of alkaloids, while others may be handicapped by these same toxic compounds. In any case, the development of tools for the genetic improvement of this plant is required, either to promote or to reduce alkaloid accumulation. Genetic improvement of $A$. mexicana by conventional breeding may probe difficult, since it is a non-domesticated specie with a narrow genetic variability within the available germplasm. Moreover, it also presents strong seed dormancy. An alternative to overcome these limitations is the introduction of new traits by Agrobacterium-mediated genetic transformation, which remains as the most employed method for transferring genes into plants cells. We are reporting transient 
$\beta$-glucuronidase (GUS) expression in prickly poppy via Agrobacterium tumefaciens transformation. To our knowledge, this is the first report of $A$. mexicana susceptibility to A. tumefaciens-mediated genetic transformation.

\section{MATERIALS AND METHODS}

Plants of Argemone mexicana were collected in the outskirts of Mérida, México $\left(20^{\circ} 58^{\prime} 00^{\prime \prime N} / 89^{\circ} 37^{\prime} 00^{\prime \prime} \mathrm{W}\right)$ and taxonomically identified by Dr. Roger Orellana-Lanza (Regional Botanical Garden, Centro de Investigación Científica de Yucatán, México). One voucher has been deposited at the CICY herbarium (F Vázquez-Flota and R Orellana 01). Seeds were collected from mature, dehiscent capsules and soaked for 2 hrs in $10 \%$ sulfuric acid, followed by subsequent washes in $70 \%$ ethanol (30 sec), sodium hypochlorite $0.6 \%$ (10 $\mathrm{min})$ and sterile distilled water. Seeds were then plated on G medium, prepared with the Phillips and Collins (1979) salts at half ionic strength, without growth regulators (pH 5.5) and incubated at $25 \pm$ $2^{\circ} \mathrm{C}$ under continuous light (photon flux density of 40-60 umol $\mathrm{m}^{-2} \mathrm{~s}^{-1}$ ), provided by fluorescent lamps (39 W; Philips, USA).

A. tumefaciens strain LBA4404 was used in all experiments. Binary vector pCAMBIA2301 (Center for the Application of Molecular Biology to International Agriculture, Canberra, Australia), containing the $\beta$ glucuronidase (uid $A$ ) and the neomycin phosphotransferase II (npt) genes within the T-DNA borders. The uid A gene in pCAMBIA2301 is interrupted by a catalase intron, which has to be removed for eukaryotic expression. Bacteria were cultured at $28^{\circ} \mathrm{C}$ in the dark in liquid YEB (Yeast Extract and Beef) medium at $\mathrm{pH} 7$, supplemented with $100 \mathrm{mg} \mathrm{l}^{-1}$ rifampicin and $100 \mathrm{mg} \mathrm{l}^{-1}$ streptomycin (YEB is $5 \mathrm{~g} \mathrm{l}^{-1}$ of each beef extract, peptone and sucrose, $1 \mathrm{~g} \mathrm{l}^{-1}$ yeast extract, and $0.5 \mathrm{~g} \mathrm{I}^{-1} \mathrm{MgSO}_{4} .7 \mathrm{H}_{2} \mathrm{O}$ ). Bacteria were made competent with $\mathrm{CaCl}_{2}$ and transformed with plasmids by heat shock (Zhang and Zeevaart, 1999). Transformed cells, harboring pCAMBIA2301, were screened on semisolid (15 $\mathrm{g} \mathrm{l}^{-1}$ bacto-agar) YEB medium, containing $100 \mathrm{mg} \mathrm{l}^{-1}$ rifampicin, $100 \mathrm{mg} \mathrm{l}^{-1}$ streptomycin and $50 \mathrm{mg} \mathrm{l}^{-1}$ kanamycin, and then cultured in $10 \mathrm{ml}$ of YEB liquid medium (pH 7) with the same antibiotics at $28^{\circ} \mathrm{C}$ for $48 \mathrm{hrs}$ in a rotatory shaker (200 $\mathrm{rpm})$. A $200 \mu \mathrm{l}$ aliquote was then diluted in $10 \mathrm{ml}$ of YEB, with the same antibiotic composition, and incubated for 24 hrs as described. Culture volume was completed to a final volume of $20 \mathrm{ml}$ with YEB, with the same antibiotic composition plus $200 \mu \mathrm{M}$ de acetosyringone (AS), and further incubated up to $5 \mathrm{hrs}$, prior to tissue inoculation.

For the transformation experiments, shoot-apex, leaf sections and roots from six-week old prickly poppy seedlings (1-4 cm high) were taken and cut with a scalpel into $1 \mathrm{~cm}$ long strips. Explants were infected with a bacterial suspension, adjusted to $0.1 \mathrm{OD}_{600} \mathrm{~nm}$, by immersion in $20 \mathrm{ml}$ of I medium (I medium is PC-L2 liquid medium with $36 \mathrm{~g} \mathrm{l}^{-1}$ glucose, $68.4 \mathrm{~g} \mathrm{l}^{-1}$ sucrose, $100 \mathrm{mg} \mathrm{l}^{-1}$ cysteine and $100 \mu \mathrm{M}$ AS, $\mathrm{pH}$ 5.2), for $30 \mathrm{~min}$. Tissues were blotted on sterilized filter paper to eliminate the bacterial excess, and then placed on CC medium (PC-L2 medium solidified with $8.0 \mathrm{~g} \mathrm{l}^{-1}$ agar, $30 \mathrm{~g} \mathrm{l}^{-1}$ sucrose, $100 \mathrm{mg} \mathrm{l}^{-1}$ cysteine and $0.05 \mu \mathrm{M}$ TDZ (Thidiazuron = 1-phenyl-3(1,2,3-thiadiazol-5-yl)-urea), $\mathrm{pH}$ 5.5). After 3 days of co cultivation at $28^{\circ} \mathrm{C}$ in the dark, explants were transferred to SF medium (PC-L2 medium supplemented $8.0 \mathrm{~g}^{-1}$ agar, 30 $\mathrm{g} \mathrm{l}^{-1}$ sucrose, $100 \mathrm{mg} \mathrm{l}^{-1}$ cysteine, $0.05 \mu \mathrm{M}$ TDZ, $100 \mathrm{mg} \mathrm{l}^{-1}$ cefotaxime and $10 \mathrm{mg} \mathrm{l}^{-1}$ kanamycin, $\mathrm{pH}$ 5.5). The cultures were maintained at $25 \pm 2^{\circ} \mathrm{C}$ under continuous light (photon flux density of 40-60 $\mu \mathrm{mol} \mathrm{m} \mathrm{m}^{-2} \mathrm{~s}^{-1}$ ), provided by fluorescent lamps.

Transient expression of GUS was histochemically assayed from 3 to 12 days after infection by staining the explants with 5-bromo-4-chloro-3-indolyl- $\beta$-D-glucuronide (X-

Table 1. Infection frequency in explants of $\boldsymbol{A}$. mexicana. Histochemical GUS assays were performed on explants twelve days after inoculation with strain LBA4404::pCAMBIA2301.

\begin{tabular}{|c|c|c|c|c|}
\hline Tissue & Infected explants & GUS positive explants & $\begin{array}{l}\text { Frequency of } \\
\text { infection }^{1}\end{array}$ & GUS foci per explant ${ }^{2,3}$ \\
\hline Shoot apex & 150 & 10 & 6.7 & $7.5(3)^{\mathrm{a}}$ \\
\hline Leaf primordia & 150 & 9 & 6.0 & $17.0(6)^{b}$ \\
\hline Leaves & 150 & 6 & 4.0 & $19.3(5)^{b}$ \\
\hline Roots & 150 & 5 & 3.3 & $2.0(1)^{\mathrm{a}}$ \\
\hline
\end{tabular}

${ }^{1}$ Infection frequency was calculated as the percentage of GUS-positive explants per total number of explants examined.

${ }^{2}$ Number of GUS foci per explant was the average of GUS positive foci in at least three independent explants with standard deviation in brackets.

${ }^{3}$ Values with different letters are statistically different $(P=0.05)$, according to Tukey's test. 
Gluc), according to Jefferson (1987). Briefly, approximately 50 explants were vacuum-infiltrated in the buffer solution for 5 min and thereafter incubated for 24 hrs at $37^{\circ} \mathrm{C}$ in the dark (Humara et al. 1999). Prior to counting the number of blue spots, explants were washed in methanol:acetone (3:1, v/v). Each blue spot was considered as a single transient GUS-expressing focus.

\section{RESULTS AND DISCUSSION}

Explants showed several blue spots produced by transient GUS expression 12 days after inoculation on leaves (Figure 1b, Figure 1c, Figure 1d, Figure 1f, and Figure 1g), leaf primordia (Figure $1 \mathrm{~h}$, Figure $1 \mathrm{j}$, Figure $1 \mathrm{k}$, and Figure $1 \mathrm{l}$ ), shoot apex (Figure 1n, Figure 1o and Figure 1p) and roots (Figure 1r). In contrast, untransformed controls did not show any blue staining (Figure 1a, Figure 1e, Figure 1i, Figure $1 \mathrm{~m}$ and Figure 1q). In roots, the LBA4404::pCAMBIA2301 vector resulted in a lower GUS expression, whereas in transformed shoot apex and leaf sections, blue staining was clearly visible.

GUS activity in tissues exposed to the bacteria can only be attributed to the actual expression of the uid $A$ gene inserted into the plant genome, since it required the removal of the catalase intron. As a difference from other species, such as Ricinus communis (Rezmer et al. 1999) or Agave fourcroydes Lem., prickly poppy did not present endogenous GUS activity.

The infection frequency, evaluated as the number of GUS expression spots per transformed explant, was generally higher after 12 days rather than 3 days after infection. Leaf primordia, leaves and shoot apex sections presented the highest infection frequencies, while roots had the lowest ones (Table 1). As expected, the infection frequency was correlated to the seedlings' age. It is interesting to note that even when the frequency of infection was similar in shoot apexes and leaves, both primordial and mature ones, a statistically significant lower number of GUS expressing foci were detected on the former tissue. This observation suggests that leaves are more sensitive to Agrobacterium infection than shot apex (Table 1).

Infection efficiency depends on several factors, including the procedure used to injure to the tissues, bacterial density and co cultivation period (Humara et al. 1999). The highest infection efficiency for Pinus pinea cotyledons was obtained by combining sonication of tissues and the induction of bacterial virulence using AS $(100 \mu \mathrm{M}) 24 \mathrm{hrs}$ prior to tissue incubation with an $1.0 \mathrm{OD}_{600 \mathrm{~nm}}$ suspension for 72 hrs. However, explants developed necrosis after 30 days. Using a dilution (1:10) of bacterial suspension reduced tissue necrosis, but also shoot formation (Humara et al. 1999). In the work presented here, tissues were excised with a scalpel blade, and inoculation was performed by culturing explants with $0.1 \mathrm{OD}_{600 \mathrm{~nm}}$ bacterial suspension for 72 hrs. Furthermore, a previous 5 hrs induction of bacterial virulence with AS was included. By using this scheme, explants presented necrotic and yellowish areas that allowed shoot formation after 45-60 days. The longer survival period of tissues could be attributed to the lower bacterial density and to the incorporation of cysteine to the media, aimed to reduce tissue darkening, due to phenolization.

Actual GUS activity was not quantified since only transient transformation was achieved. Nevertheless, it is certain that tissues were genetically transformed given the fact that the catalase intron, which interrupts the uid A sequence in the vector (pCAMBIA2301), was removed during RNA processing in eukaryotic cells. Furthermore, A. mexicana tissues did not display endogenous Gus activity (Figure 1). To our knowledge, this is the first report of T-DNA transfer to A. mexicana tissues via A. tumefaciens. This procedure will allow us to introduce relevant genes in order to control of the synthesis of secondary metabolite through metabolic engineering (Samanani et al. 2002; Frick et al. 2004).

\section{REFERENCES}

FACCHINI, Peter J. Alkaloid biosynthesis in plants: biochemistry, cell biology, molecular regulation, and metabolic engineering applications. Annual Review of Plant Physiology and Plant Molecular Biology, June 2001, vol. 52, p. 29-66.

FRICK, Susanne; CHITTY, Julie A.; KRAMELL, Robert; SCHMIDT, Jürgen; ALLEN, Robert S.; LARKIN, Phillip J. and KUTCHAN, Toni M. Transformation of opium poppy (Papaver somniferum L.) with antisense berberine bridge enzyme gene (anti-bbe) via somatic embryogenesis results in an altered ratio of alkaloids in latex but not in roots. Transgenic Research, December 2004, vol. 13, no. 6, p. 607-613.

GARCIA, V.P.; VALDES, F.; MARTIN, R.; LUIS, J.C.; AFONSO, A.M. and AYALA, J.H. Biosynthesis of antitumoral and bactericidal sanguinarine. Journal of Biomedicine and Biotechnology, 2006, vol. 2006, no. 63518, p. 1-6.

HUMARA, J.M.; LOPEZ, M. and ORDAS, R.J. Agrobacterium tumefaciens-mediated transformation of Pinus pinea L. cotyledon: an assessment of factors influencing the efficiency of uidA gene transfer. Plant Cell Reports, November 1999, vol. 19, no. 1, p. 51-58.

JEFFERSON, R. Assaying chimeric genes in plants: the GUS gene fusion system. Plant Molecular Biology Reporter, December 1987, vol. 5, no. 4, p. 387-405.

PHILLIPS, G.C. and COLLINS, G.B. In vitro tissue culture of selected legumes and plant regeneration from callus culture of red clover. Crop Science, January 1979, vol. 19, no. 1, p. 59-64.

RAO, T.V.R. and DAVE, Y.S. Morpho-histogenic studies of the fruit wall of Argemone mexicana L. (Papaveraceae). 
Acta Botanica Hungarica, September 2001, vol. 43, no. 34, p. 391-401.

REZMER, Claudia; SCHLICHTING, Ralf; WACHTER, Rebecca and ULLRICH, Cornelia I. Identification and localization of transformed cells in Agrobacterium tumefaciens-induced plant tumors. Planta, October 1999, vol. 209, no. 4, p. 399-405.

SAMANANI, Nailish; PARK, Sang-Un and FACCHINI, Peter J. In vitro regeneration and genetic transformation of the berberine-producing plant, Thalictrum flavum ssp. glaucum. Physiologia Plantarum, September 2002, vol. 116, no. 1, p. 79-86.

ZHANG, H.-X. and ZEEVAART, J.A.D. An efficient Agrobacterium tumefaciens-mediated transformation and regeneration system for cotyledons of spinach (Spinacia oleracea L.). Plant Cell Reports, March 1999, vol. 18, no. 7-8, p. 640-645. 